\title{
FAKTOR-FAKTOR YANG MEMPENGARUHI KEPUTUSAN WISATAWAN MENGGUNAKAN TRANSPORTASI BERBASIS APLIKASI DI PT. GOJEK INDONESIA
}

\author{
Nora Ronia Pangaribuan \\ Ni Made Sofia Wijaya \\ Ni Putu Eka Mahadewi \\ Email : norapangaribuan@gmail.com \\ PS. S1 Industri Perjalanan Wisata \\ Fakultas Pariwisata UNUD
}

\begin{abstract}
Nowadays, internet is an essential contribution to tourism development. The internet offers the potential to make the information and booking facilities. It also provides a tool a communication between tourism suppliers, intermediaries, as well as end-consumers. Gojek is one of transport based application that is currently used by tourists to take advantage of low cost offered. The purpose of this research is to determine the affecting and dominant factor in affecting tourist's decision to use GoJek application.

Data were collected through questionnaires, interviews, literature study and documentation. Sample of this research used purposive sampling technique with number of sampling are 100 respondents, focused on tourists who have been using the GoJek application. This research used six factors which consist of seventeen indicators. The results of factors analyzed affecting interpreted as external factors, psychological, internal, motivation and labor saving. The most dominant factor is external consists by a variable reference, cultural, economic, price competition, perception of security and internet trusted. Factors which eliminated in this research is use every time because tourists not necessarily used GoJek application at any time for order transportation while holiday in Bali.
\end{abstract}

Keywords: Purchasing Decision, Transportation Applications.

\section{PENDAHULUAN}

Dengan adanya internet, informasi yang dibutuhkan untuk suatu perjalanan wisata dapat diakses dengan mudah terutama dalam bentuk World Wide Web atau Web serta dapat juga diraih melalui aplikasi-aplikasi yang dapat diunduh di Playstore pada smartphone. Wisatawan sekarang dapat langsung berhubungan dengan sumber informasi tanpa melalui perantara.

Melalui informasi dari internet, suatu penawaran destinasi dapat sampai ke konsumen yaitu calon wisatawan sendiri. Seiring dengan kemajuan dewasa ini maka internet berkembang pesat sebagai teknologi erat dalam dunia yang menjadi suatu kebutuhan yang mendesak bagi calon wisatawan yang mana wisatawan diberikan banyak variasi harga dan rekomendasi. Tekanan pada kebutuhan informasi mempercepat perkembangan internet yang mampu menyediakan informasi tanpa dibatasi oleh jarak dan waktu dalam lingkup secara global. Bermodalkan satu click pada halaman browser ataupun aplikasi pada smartphone, calon wisatawan mampu menemukan informasi tentang satu daerah destinasi.

Keberadaan aplikasi di Indonesia yang kemudian menjadi trend yaitu transportasi berbasis aplikasi yang dilirik sebagai model $e$ commerce dikarenakan transportasi sendiri merupakan hal yang dasar untuk kehidupan manusia dalam melakukan perpindahan dari suatu tempat ke tempat lain. Salah satu transportasi berbasis aplikasi yang ada di Indonesia yaitu GoJek. 
Berdasarkan observasi awal yang dilakukan oleh peneliti melalui wawancara bahwa kepada driver GoJek dapat dilihat bahwa wisatawan mulai tertarik menggunakan aplikasi GoJek untuk mengantarkannya ke suatu tempat ketika wisatawan tersebut berlibur di Bali. Keberadaan aplikasi GoJek menempati posisi pertama sebagai "Mobile App Ranking" dengan kategori transportasi di Indonesia. GoJek juga mengalahkan posisi transportasi berbasis aplikasi lainnya seperti Grab Taxi dan Uber. Fenomena yang dapat dilihat adalah wisatawan mulai melibatkan keberadaan internet sebagai kebutuhan untuk perjalanan termasuk mencari informasi dan transportasi selama berlibur di Bali.

Adapun penelitian yang dimaksud adalah bertujuan untuk mengetahui faktor yang mempengaruhi keputusan wisatawan yang mulai ikut menggunakan transportasi berbasis aplikasi GoJek untuk memesan transportasi ojek atau sepeda motor.

\section{METODE PENELITIAN}

Adapun lokasi penelitian ini dikhususkan di wilayah Kuta. Sedangkan, definisi operasional variabel yang digunakan terdiri dari 6 variabel yang berjumlah 17 indikator yang dapat dilihat pada Tabel 1 .

Tabel 1. Variabel Yang Digunakan

\begin{tabular}{|c|c|c|}
\hline No & Faktor & Indikator \\
\hline \multirow[t]{3}{*}{1.} & Faktor & a. Persepsi \\
\hline & Psikologis & b. Motivasi \\
\hline & & c. Pembelajaran \\
\hline \multirow[t]{3}{*}{2.} & Faktor & a. Sarana \\
\hline & Situasional & b. Penggunaan produk \\
\hline & & c. Kondisi pembelian \\
\hline \multirow[t]{3}{*}{3.} & Faktor Sosial & a. Keluarga \\
\hline & & b. Referensi \\
\hline & & c. Budaya \\
\hline \multirow[t]{2}{*}{4.} & Faktor Harga & a. Hemat \\
\hline & & b. Persaingan harga \\
\hline \multirow[t]{4}{*}{5.} & Faktor & a. Persepsi keamanan \\
\hline & Kepercayaan & b. Kepercayaan pada \\
\hline & & c Kenercavaan nada \\
\hline & & $\begin{array}{l}\text { aplikasi } \\
\text {. }\end{array}$ \\
\hline \multirow[t]{3}{*}{6.} & Faktor & a. Menghemat waktu \\
\hline & Kenyamanan & b. Menghemat tenaga \\
\hline & & $\begin{array}{l}\text { c. Berbelanja setiap } \\
\text { waktu }\end{array}$ \\
\hline
\end{tabular}

Sumber: Sangadji dkk, 2013 dan Hasslinger et.al, 2007
Pada Tabel 1 ini digunakan variabel untuk mengukur faktor-faktor yang mempengaruhi keputusan wisatawan untuk menggunakan transportasi berbasis aplikasi GoJek. Jenis data yang digunakan yakni data deskriptif kuantitatif. Sedangkan teknik pengumpulan data yang digunakan adalah kuesioner yang disebarkan di daerah Kuta Bali, studi kepustakaan melalui berbagai literatur, buku, jurnal dan penelitian sebelumnya, wawancara tidak disengaja sebelum penelitian kepada driver GoJek yang melatarbelakangi penelitian ini serta untuk mengetahui operasional dari Go-Drive. Selain itu, terdapat pula wawancara kepada responden untuk memperkuat hasil analisis faktor dan teknik dokumentasi dengan mendokumentasikan beberapa foto untuk melihat situasi GoJek ketika membawa penumpang, ketika melakukan penelitian baik wawancara ataupun pengisian kuesioner. Untuk mengolah data kuesioner yang didapatkan, maka dilakukan proses uji validitas, uji realibilitas dan analisis faktor yang dilakukan pada program SPSS 16.0 for Windows.

\section{HASIL DAN PEMBAHASAN}

PT. GoJek Indonesia merupakan perusahaan aplikasi sosial entrepreneurship yang akrab dikenal dengan sebutan GoJek. GoJek mulai beroperasi pada tahun 2015 di Pulau Bali. GoJek sendiri memiliki 12 fitur layaanan jasa yang dapat digunakan pada aplikasinya dan salah satunya yaitu fitur $\mathrm{Go}$ Ride.

Go-Ride merupakan fitur dari GoJek yang berfungsi untuk memesan transportasi sepeda motor atau ojek. Fitur Go-Ride akan menghubungkan driver dengan wisatawan yang hendak melakukan perjalanan dengan maksimal jarak tempuh $25 \mathrm{~km}$.

Penelitian ini didasarkan pada 100 responden dengan menggunakan kuesioner yang diberikan pada wisatawan yang sudah menggunakan GoJek di Kuta, Bali.

Responden berdasarkan jenis kelamin didominasi dengan laki-laki sebanyak 57\%, berdasarkan usia didominasi dengan usia 2635 tahun, berdasarkan daerah asal didominasi dengan wisatawan dari Indonesia atau wisatawan domestik sebanyak $85 \%$, berdasarkan pekerjaan didominasi dengan pelajar/mahasiswa sebesar 35\%, dan berdasarkan pengorganisasian perjalanan 
didominasi dengan individual/sendiri sebesar $71 \%$.

Hasil uji validitas menyatakan bahwa 17 indikator dinyatakan valid. Hasil uji realibiltas dalam penelitian ini memiliki Guttman SplitHalf Coefficient sebesar 0,907 sehingga dapat dikatakan realibel.

Proses awal dalam analisis faktor yaitu menentukan jumlah indikator yaitu 17 indikator. Proses selanjutnya yaitu uji kelayakan variabel. Nilai Barrlet Test of Sphenricity yang diperoleh adalah 575.974 dengan signifikasi 0,000 . Ini menunjukkan bahwa peluang terjadi kesalahan untuk variabel tidak independent sebesar $0 \%$ dengan demikian variabel memiliki korelasi Sedangkan, nilai Uji Kaiser Mayer Olkin (KMO) sebesar 0,802 yang menunjukkan syarat dapat dilanjutkan ke tahap selanjutnya.

Uji Measure Of Sampling Aseaquancy (MSA) merupakan proses selanjutnya. Nilai MSA harus lebih besar dari 0,5 dan semua indikator dinyatakan dapat diproses ke tahap selanjutnya. Selajutnya proses faktor yang terbentuk sebanyak 5 faktor dengan nilai total cumulative of variance sebesar $63,057 \%$, hal ini menunjukkan bahwa kelima faktor tersebut menjelaskan $63,057 \%$ total varian variabel yang mempengaruhi keputusan wisatawan menggunakan transportasi berbasis aplikasi yaitu GoJek.

Selanjutnya proses rotasi faktor yang memiliki syarat factor loading $>0,5$. Dari ketujuh belas indikator maka terdapat satu indikator yang tereliminasi.

Kelima faktor yang digunakan kemudian diintepretasikan. Faktor 1 diberi nama faktor eksternal yang memiliki nilai eigenvalue sebesar 5,547 terdiri dari indikator referensi, budaya, hemat, persaingan harga, persepsi keamanan, dan kepercayaan pada internet.. Faktor 2 diberi nama faktor psikologis yang memiliki nilai eigenvalue sebesar 1,519 terdiri dari indikator persepsi, pembelajaran dan sarana.. Faktor 3 diberi nama faktor internal yang memiliki nilai eigenvalue sebesar 1,410 terdiri dari indikator penggunaan produk, kondisi pembelian, dan keluarga.. Faktor 4 diberi nama faktor motivasi yang memiliki nilai eigenvalue sebesar 1,226 terdiri dari indikator motivasi, kepercayaan pada aplikasi, dan menghemat waktu.. Faktor 5 diberi nama faktor menghemat tenaga yang memiliki nilai eigenvalue sebesar 1,016 terdiri indikator menghemat waktu sendiri.
Karakteristik responden dibagi menjadi karakteristik berdasarkan jenis kelamin, usia, daerah asal, pekerjaan dan pengorganisasian perjalananan. Angka yang ditampilkan berdasarkan karakteristik jenis kelamin tidak memiliki banyak perbedaan dan cukup berimbang karena hanya terdapat selisih sedikit perbedaan antara responden laki-laki dan perempuan. Hal ini menunjukkan laki-laki dan perempuan memiliki ketertarikan yang sama untuk menggunakan aplikasi GoJek. Karakteristik berdasarkan usia didominasi dengan usia 26-35 yang menunjukkan bahwa pada kategori usia produktif. Karakteristik berdasarkan daerah asal didominasi dengan wisatawan domestik dari berbagai daerah dikarenakan GoJek sendiri merupakan aplikasi yang hanya beroperasi di Indonesia dan GoJek sendiri merupakan aplikasi yang berasal dari Indonesia. Karakteristik berdasarkan pekerjaan didominasi dengan wisatawan yang bekerja sebagai pelajar/mahasiswa. Hal ini dikarenakan pelajar/mahasiswa cenderung menginginkan hal-hal yang lebih murah karena sebagian besar pelajar/mahasiswa belum memiliki penghasilan tetap. GoJek menawarkan harga yang lebih ekonomis dibandingkan transportasi wisata lainnya. Karakteristik wisatawan berdasarkan pengorganisasian perjalanan didominasi dengan perjalanan yang dilakukan sendiri/individual. hal ini disebabkan karena perjalanan dengan pengorganisasian sendiri lebih fleksibel dan tidak memiliki panduan perjalanan sehingga wisatawan dengan pengorganisasian sendiri dapat memenuhi perjalanannya baik ke destinasi wisata atau ke tempat lainnya dengan menggunakan fitur GoRide pada aplikasi GoJek.

Hasil dari analisis data menggunakan analisis faktor dari program SPSS maka didapatkan hasil yang menunjukkan data bahwa dari 6 (enam) faktor awal dengan total 17 indikator tersebut diatas, maka diperoleh lima faktor terbentuk yang mempengaruhi keputusan wisatawan menggunakan aplikasi GoJek yaitu : pertama, faktor eksternal yang terdiri dari variabel referensi, budaya, hemat, persaingan harga, persepsi keamanan, dan kepercayaan pada internet. Kedua, faktor psikologis yang terdiri dari variabel persepsi, pembelajaran dan sarana. Ketiga, faktor internal yang terdiri dari variabel penggunaan produk, kondisi pembelian, dan keluarga. Keempat, faktor motivasi yang terdiri dari 
motivasi, kepercayaan pada aplikasi, dan menghemat waktu. Kelima, faktor menghemat tenaga yang terdiri dari faktor menghemat tenaga itu sendiri.

Dalam 17 indikator yang diuji melalui analisis faktor maka, terdapat satu faktor yang tereliminasi yaitu faktor berbelanja setiap waktu. Hal ini dikarenakan nilai faktor loading yang $<0,5$ sehingga total indikator yang mempengaruhi keputusan wisatawan untuk menggunakan aplikasi GoJek berjumlah enam belas.

Berdasarkan hasil penelitian maka yang menjadi faktor utama yang paling dominan dalam mempengaruhinya yaitu faktor eksternal. Hasil penelitian ini dikuatkan dengan hasil wawancara yang menyatakan bahwa wisatawan menggunakan aplikasi GoJek karena sudah mendapatkan referensi dari teman atau kenalan yang sudah pernah menggunakan GoJek baik di Bali ataupun luar Bali. Terdapat juga alasan budaya yang sudah terbiasa dalam memesan atau membeli secara online. Faktor persaingan harga juga merupakan faktor yang mempengaruhi karena wisatawan merasa lebih murah menggunakan GoJek dibandingkan ojek-ojek pangkalan ataupun taksi. Wisatawan lebih menyukai harga yang pasti yang ditampilkan aplikasi GoJek daripada harus tawar-menawar pada ojek-ojek pangkalan dengan harga yang tidak pasti.

Selain itu, variabel persepsi keamanan dan kepercayaan terhadap internet merupakan variabel yang penting bagi wisatawan, karena wisatawan merasa aman ketika memesan GoJek yang mana identitas dari driver dapat diketahui pada aplikasi dan berada pada naungan perusahaan yang jelas dan terdaftar dan wisatawan dapat memberikan penilaian dan komentar pada layanan driver sesudah menggunakan aplikasi GoJek Dari kelima faktor tersebut, faktor yang dominan dalam memberikan kontribusi menentukan keputusan konsumen memesan GoJek di Bali adalah faktor yang terbentuk dengan nilai faktor loading tertinggi dari kelima faktor terbentuk. Adapun faktor eksternal terdiri dari variabel referensi, budaya, hemat, persaingan harga, persepsi keamanan, dan kepercayaan pada internet.

\section{SIMPULAN DAN SARAN}

Simpulan

Berdasarkan hasil analisis yang dilakukan terkait faktor-faktor yang mempengaruhi wisatawan menggunakan aplikasi GoJek maka dapat disimpulkan sebagai berikut :

1. Faktor-faktor yang mempengaruhi keputusan wisatawan menggunakan aplikasi GoJek terdiri dari 5 (lima) faktor yaitu:

a. Faktor eksternal terdiri dari variable referensi, budaya, hemat, persaingan harga, persepsi keamanan, dan kepercayaan pada internet.

b. Faktor psikologis terdiri dari variabel persepsi, pembelajaran dan sarana

c. Faktor internal terdiri dari variabel penggunaan produk, kondisi pembelian, dan keluarga.

d. Faktor motivasi terdiri dari motivasi, kepercayaan pada aplikasi, dan menghemat waktu.

e. Faktor menghemat tenaga hanya memiliki 1 variabel saja yaitu variabel menghemat tenaga tersebut.

2. Faktor yang memiliki kontribusi paling besar dalam mempengaruhi keputusan keputusan wisatawan menggunakan GoJek adalah faktor pertama yakni faktor eksternal.

\section{Saran}

1. Bagi PT.Gojek Indonesia, agar tetap menjaga dan mempertahankan faktorfaktor yang mempengaruhi keputusan wisatawan untuk menjaga kepercayaan wisatawan. Selain itu, PT.Gojek Indonesia juga harus memperhatikan salah satu indikator yang terliminasi karena nilai eingenvalue rendah yaitu faktor berbelanja setiap waktu untuk dapat menentukan strategi ke depannya agar wisatawan lebih sering menggunakan GoJek.

2. Bagi peneliti selanjutnya, terdapat beberapa saran yaitu menambahkan kuota sampling pada penelitian, menambah identitas responden agar karakteristik pengguna GoJek dapat diketahui secara spesifik serta membedakan hasil data antara wisatawan asing dan wisatawan domestik untuk dapat melihat jika terdapat perbedaan antara penilaian 
Jurnal IPTA

ISSN : 2338-8633

Vol. 4 No. 2, 2016

wisatawan asing dan wisatawan domestik.

\section{DAFTAR PUSTAKA}

Anonim. 2016. Mobile App Rangking. https://similiarweb/Gojek. Diakses pada 5 April 2016.

2016. Layanan Go-Ride. https://www.go-jek.com. Diakses 2 Agustus 2016.

Hasslinger, Anders et al. 2007. Consumer Behaviour In Online Shopping. Kristianstad University.

Sangadji, Etta Mamang dan Sopiah. 2014. Perilaku Konsumen (Yogyakarta, Andi Offset). 